inherit only one $\mathrm{X}$ chromosome, from their mothers, and so must activate the same Xlinked genes. In the British study, researchers led by Ian Craig of King's College London found that in some traits linked to intelligence, such as verbal skills and good social behaviour, male twins were more alike than female twins ${ }^{7}$.

But why should the $\mathrm{X}$ chromosome have emerged as a hotspot for genes influencing our cognitive abilities? Evolutionary geneticists believe that the two mammalian sex chromosomes, $\mathrm{X}$ and $\mathrm{Y}$, were once identical. As mammals began to diverge from their reptilian ancestors, some 300 million years ago, the proto- $\mathrm{X}$ and proto- $\mathrm{Y}$ chromosomes took on the role of determining an individual's sex. Both initially started accumulating genes from elsewhere in the genome, but over time the two chromosomes began to grow apart; the Y started to shrink and lost many of its genes.

\section{Solid foundation}

Eventually, the sex chromosomes diverged to the point where they were no longer able to exchange genetic material during the cell divisions that give rise to sperm and eggs, as do the members of every other pair of chromosomes. This has left the $\mathrm{X}$ chromosome as one of the most stable in the mammalian genome - which paradoxically may have exposed its genes to more intense pressure to evolve.

The $\mathrm{X}$ chromosome gets a chance to shine, or to fail miserably, each time it passes through the male line. Because a male carries only one copy, any new mutations are revealed in all their glory. And because successful males have the potential to sire very large numbers of children with multiple partners, mutations on the $\mathrm{X}$ chromosome that are advantageous to both sexes can spread rapidly through a population.

In our own species, where intelligence and social skills are thought to be central to success, genes on the $\mathrm{X}$ chromosome seem to have evolved rapidly to provide us with the necessary brain power. "If higher cognitive abilities were a critical step in our own evolution, it makes sense that you might find those functions on the X chromosome," says Hunt Willard, a human geneticist and director of the Institute for Genome Sciences and Policy at Duke University in Durham, North Carolina.

Provocatively, researchers led by Horst Hameister at the University of Ulm in Germany speculate that this process was driven by sexual selection ${ }^{3}$. Early in human evolution, they suggest, females developed a preference for intelligent males. According to their theory, the genes for super-intelligence and for the preference of intelligent males were closely linked, and so were inherited together. And because superior intelligence also aided survival, the process wasn't kept in

\section{IMAGE UNAVAILABLE FOR COPYRIGHT REASONS}

Double vision: by looking for differences in the behaviour of twin girls, geneticists are trying to find out how $\mathrm{X}$ chromosomes (top) influence mental ability.

check by natural selection - unlike other sexually selected characteristics such as the peacock's tail, which makes its bearers more vulnerable to predators.

Many of the genes on the X chromosome associated with human brain function seem to have distant relatives with different functions in other vertebrates, such as chickens and fish $^{8}$. So in boosting our cognitive abilities, the X chromosome seems to have co-

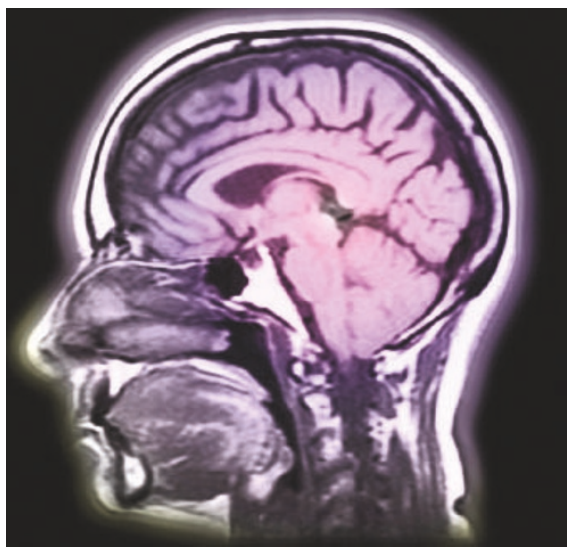

Head start: our large brains may have evolved thanks to the action of the $\mathrm{X}$ chromosome. opted a diverse range of existing genes, rather than evolving a new set of genetic sequences for the purpose. "These old genes are getting new use," says Hameister.

In some instances, geneticists have pinpointed genes on the $\mathrm{X}$ chromosome that still seem to be in the process of adopting new roles in the brain. For instance, a gene called JARID1C seems to be evolving from a similar gene called JARID1D, which is found on the $\mathrm{Y}$ chromosome. If men inherit a damaged version of the JARID1C gene on their single $\mathrm{X}$ chromosome, they develop mental disabilities. The fact that the healthyY chromosome version cannot compensate for its defective cousin hints that JARID1C is becoming more crucial to the brain as it evolves?

\section{Personality profiles}

Geneticists are now gearing up to go after other X-linked genes that may help explain what makes us human. In London, Craig's team plans to identify twins who score high or low on certain 'people skills', such as sharing their toys and volunteering help to others. The researchers will then use gene chips to scan the twins' DNA, looking for particular genetic variations that correlate with these traits. Once they find a region of DNA that seems to link to a particular trait, the group will look at the detailed sequence of individual chromosomes to try to pin down the exact gene involved. The X chromosome data, with its wealth of information about human brain genes, is likely to feature prominently in this endeavour.

Other researchers plan to continue the quest for genes involved in X-linked brain disorders. Every two years, for instance, scientists meet as part of a European consortium that catalogues genes involved in such conditions. Researchers believe that the information so far gleaned about human brain function from these studies barely scratches the surface.

If we want to understand the cognitive ' $X$ factor' that separates us from the rest of the animal kingdom, then it seems that the $\mathrm{X}$ chromosome is the place to start looking. In the meantime, Summers and his acolytes can chew on this thought: even if there's any truth in the idea that men are more suited to a career in science than women, they just might owe this mental predisposition to the 'girly' chromosome.

Erika Check is Nature's Washington biomedical correspondent.

1. Ross, M. T. et al. Nature 434, 325-337 (2005).

2. Johnson, G. E. J. Psycho-Asthenics 2, 26-32 (1897).

3. Zechner, U. et al. Trends Genet. 17, 697-701 (2001).

4. Ropers, H.-H. \& Hamel, B. C. J. Nature Rev. Genet. 6, 46-57 (2005).

5. Verkerk, A. J. et al. Cell 65, 905-914 (1991).

6. Oostra, B. A. \& Chiurazzi, P. Clin. Genet. 60, 399-408. (2001).

7. Loat, C. S., Asbury, K., Galsworthy, M. J., Plomin, R. \& Craig, I. W. Twin Res. 7, 54-61 (2004).

8. Kohn, M., Kehrer-Sawatzki, H., Vogel, W., Graves, J. A. M. \& Hameister, H. Trends Genet. 20, 598-603 (2004).

9. Jensen, L. R. et al. Am. J. Hum. Genet. 76, 227-236 (2005). 